\title{
Leprosy control: the rationale of integration
}

\author{
A LORETTI \\ WHO/EPR/HQ, 1211 Geneva 27, Switzerland
}

\section{Accepted for publication 17 March 1989}

\begin{abstract}
Summary After considering the situation and the perspectives of integration and the drawbacks that a vertical approach can represent for leprosy control, the author proposes the framework of control programmes as a systemic model for comprehensive health care. The structure that health services in developing countries are adopting in order to implement PHC allows for an horizontal integration of specific activities; conversely, activities which have already proved their value for leprosy control can easily enlarge their scope and include other prevalent conditions. Integration leads to an improvement in patients' and health workers' attitudes; provided that the necessary supervision is guaranteed, integration is feasible and warrants more effective patients' care and a better exploitation of resources in order to reduce the specific risk in the community.
\end{abstract}

\section{Introduction}

This paper is based on experience gathered in a developing country, of a leprosy control programme whose strategical guidelines were subsequently adopted for the management of the national health system. ${ }^{1}$ Its objective is to stimulate discussion on the various ways in which the contents and functions of leprosy control can be effectively incorporated in the 'horizontal' framework of the general health services. This may possibly necessitate confining the specific component to technical advice and supervision and central referral facilities.

\section{The meaning and implications of integration-general considerations}

'Integration' of leprosy control has been a matter of debate for a long time. The term is generally taken to mean, either the horizontal implementation of activities previously carried out by a vertical programme - that is an integration of resources ${ }^{2}$ - or a combination of various objectives under a single vertical programme - as in leprosy-TB control. ${ }^{3}$ Another concept is 'Integration' between different leprosy control programmes, such as between government and voluntary agencies or between neighbouring countries, implying standardization of criteria to improve performance, results and evaluation.

The application of MDT has opened up new perspectives for leprosy control which have fostered the specific, vertical approach with the aim of eradicating the disease, so that today, most, if 
not all, control programmes continue to be run on vertical lines. It is by no means certain, however, that this strategy will succeed. Leprosy disappeared from several countries before the introduction of any chemotherapy and declined markedly in other countries during the era of dapsone monotherapy, concomitant with, and probably largely due to, socio-economic development. ${ }^{4}$ Further, experience in tuberculosis control, shows that highly effective multiple drug regimens can be applied for many years without any great impact on the incidence of the disease in poorer countries. ${ }^{5}$ Accordingly, the integrated approach still merits serious consideration.

Countries with a high prevalence of leprosy generally face complex health problems and have to optimize the use of the resources available. Their populations are exposed simultaneously to many risk factors - each of which may be specific for a certain condition, but which together constitute a serious threat to health or life-in the face of which any action which is too specific is inevitably of limited effectiveness.

It is of note that, in general, public opinion considers that 'integration' already exists; people do not distinguish between a vertical programme and the general health services, and patient compliance, being dependent on trust in the effectiveness of treatment, may be influenced as much by the failure, for example, of treatment for epilepsy in a family member as by the advertized merits of antileprosy treatment. ${ }^{6}$

An overall improvement in general health services is a step towards a more effective leprosy control and, conversely, leprosy control can contribute to such an improvement. Indeed, it constitutes a good model, organized as it is in a comprehensive programme, even within the limits of its specific objectives, catering for a wide range of patients' needs and reaching out into the community. Specific tasks are defined at each level and effectively integrated in terms of planning and implementation. Due attention is given to standards of treatment, adequate technologies and health education, while the need for permanent supervision and training of staff is fully recognized. Its management is increasingly geared to information systems and provides for local decisionmaking within the national strategy, especially on account of variations of incidence and prevalence from area to area. All these features are inherent in primary health care (PHC), and any experience gathered in their application in a specific field ought to be relevant to the management of a general health system.

Leprosy control has always emphasized the importance of health education and community involvement which is the core of PHC. The role played by voluntary agencies and charitable institutions is of particular note, both in relation to the community - which of ten shows a preference for them because they offer more comprehensive care and often have more highly motivated staff - and in relation to the wider political debate about development, international aid and health.

\section{A public health approach}

The majority of publications on leprosy concern it's microbiology, immunology, pharmacology and clinical aspect, while those on its control in the community are written from the standpoint of epidemiology, anthropology or sociology. Some authors ${ }^{7}$ have discussed leprosy control in the perspective of PHC, but in the main these papers have been limited to the grounding of vertical programmes in the community (it should, however, be emphasized that village health workers can reasonably be expected to undertake leprosy control ${ }^{8}$ only if the superior levels of the system can provide integrated care for all the problems likely to arise in a community-based programme). There are very few papers - or even editorials - dealing with operational aspects of integration (with the exception of some from integrated leprosy-TB projects) and this is possibly due to lack of experience. The greatest need at the present time, however, is to improve the operational efficiency of leprosy control programmes and this can best be achieved by application of the principle of public health administration as enunciated by Leavell \& Clark in their classical model of the natural 


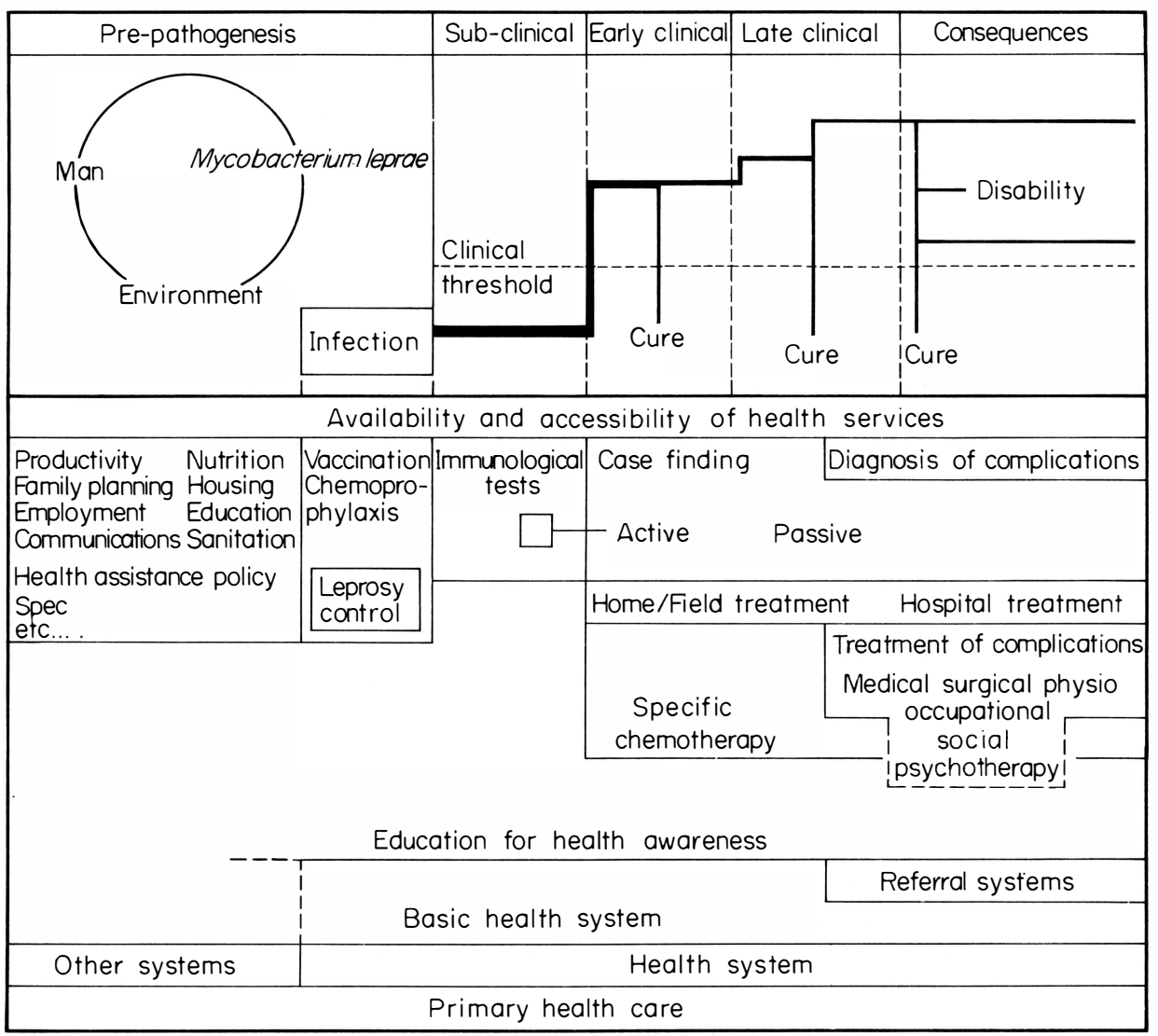

Figure 1. Leprosy control: activities, levels and resources (Loretti 1983 after Leavell \& Clark).

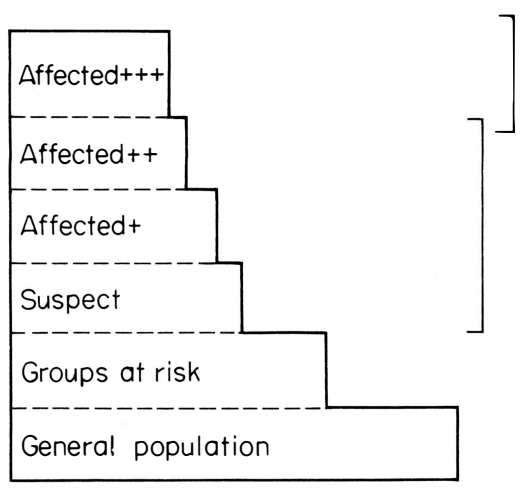

Tertiary prevention

Secondary prevention

Specific prophylaxis

Health promotion

Figure 2. Public health programmes and population (Loretti 1986). 


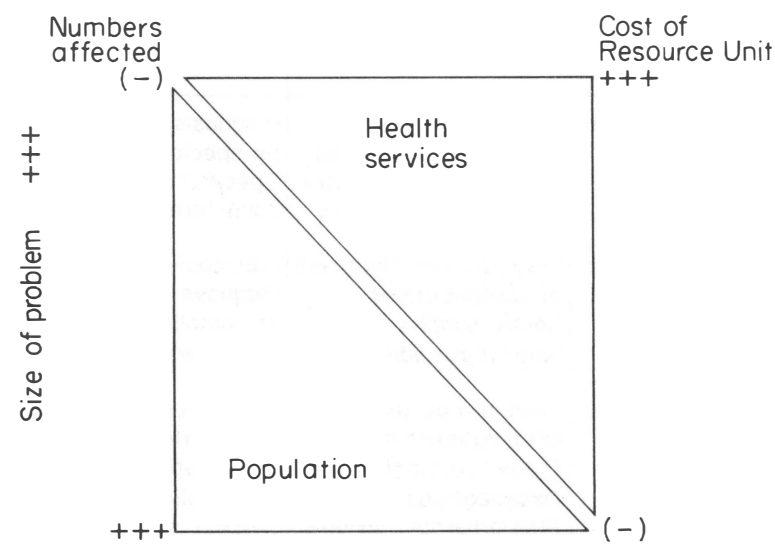

Figure 3. Health problems in a population and costs of health resources (Loretti 1986).

history of disease. ${ }^{9}$ Figure 1 illustrates how the general features of leprosy and its control fit into the model; the feasibility of integration can then be assessed by analysis of the model along two different lines.

\section{The population-services analysis}

The first analysis relates the health system to the population, in order to ensure that its structure is adequate to undertake leprosy control activities.

Figure 2 illustrates how the general population are the object of health promotion, groups at risk need specific prophylaxis, while suspects and individuals increasily affected need actions directed at secondary and tertiary prevention.

Figure 3 shows that in the population, the highest number of individuals can be cared for at the primary level of the health system at minimum cost; as the extent of the problem increases, the
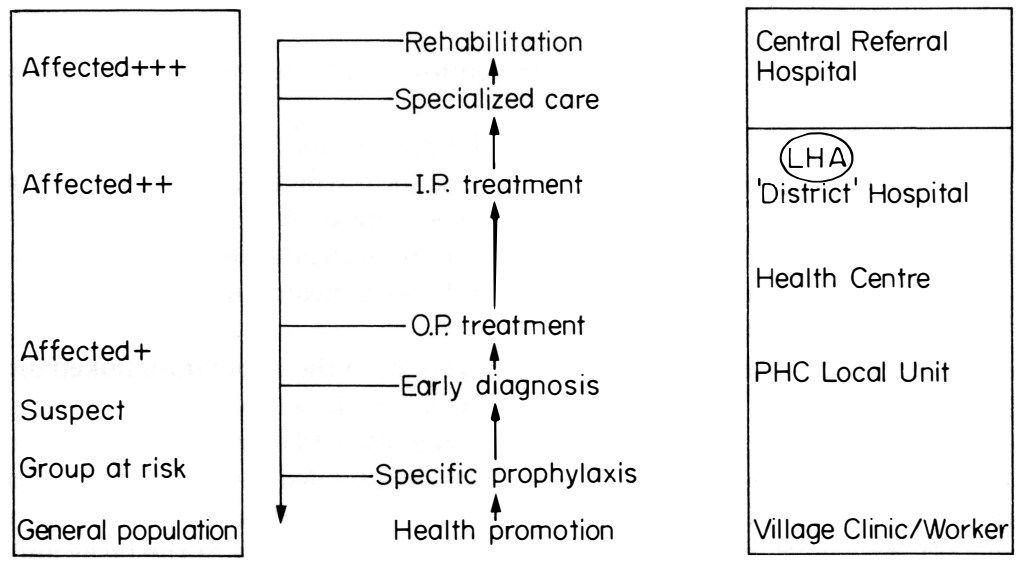

Figure 4. Health care delivery: relation between the population served, the services and their activities. LHA, Local Health Authority (Loretti 1986). 


\begin{tabular}{|c|c|c|c|c|}
\hline & M.C. health care & Leprosy control & TB control & \\
\hline Affected +++ & $\begin{array}{l}\text { Diagnosis, treatment } \\
\text { Special care: } \\
\text { Paediatrics and } \\
\text { obstetrics }\end{array}$ & $\begin{array}{l}\text { Diagnosis, treatment } \\
\text { by specialist; orthesis } \\
\text { Reconstructive surgery } \\
\text { Long-term admissions }\end{array}$ & $\begin{array}{l}\text { Diagnosis, treatment } \\
\text { by specialist; } \\
\text { Specific surgery } \\
\text { Long-term admissions }\end{array}$ & $\begin{array}{l}\text { Central } \\
\text { Referral } \\
\text { Hospital }\end{array}$ \\
\hline Affected ++ & $\begin{array}{l}\text { I.P. treatment, Paed. } \\
\text { and obstetrics } \\
\text { Hospital delivery } \\
\text { Premature care }\end{array}$ & $\begin{array}{l}\text { Diagnosis and treatment } \\
\text { of complications } \\
\text { Septic surgery } \\
\text { Short-term admissions }\end{array}$ & $\begin{array}{l}\text { Lab. confirmation } \\
\text { Diagnosis and treatment } \\
\text { of complications } \\
\text { Short-term admissions }\end{array}$ & $\begin{array}{l}\text { LCHA } \\
\text { 'District' Hospital }\end{array}$ \\
\hline Affectedt & $\begin{array}{l}\text { O.P. Treatment, Paed } \\
\text { and obstetrics } \\
\text { Assisted delivery } \\
\text { FP counselling } \\
\text { IUD insertion } \\
\text { Umbilical Care } \\
\text { PCM diagnosis and } \\
\text { follow-up }\end{array}$ & $\begin{array}{l}\text { Clinical-Lab diagnosis } \\
\text { OP treatment and } \\
\text { Follow-up, Spotting of } \\
\text { complications } \\
\text { Physiotherapy, sandals } \\
\text { suspect screening }\end{array}$ & $\begin{array}{l}\text { Clinical-Lab diagnosis } \\
\text { OP treatment and } \\
\text { follow-up, spotting } \\
\text { of complications } \\
\text { Suspect screening }\end{array}$ & Health Centre \\
\hline Suspec $\uparrow$ & $\begin{array}{l}\text { Family observation } \\
\text { Special follow-up } \\
\text { Referral }\end{array}$ & $\begin{array}{l}\text { Skin screening, } \\
\text { Family observation, } \\
\text { Special follow-up, } \\
\text { Referral }\end{array}$ & $\begin{array}{l}\text { Cough screening, } \\
\text { Sputum collection, } \\
\text { Referral, } \\
\text { Family observation, }\end{array}$ & PHC local unit \\
\hline Group at risk & $\begin{array}{l}\text { Breastfeeding } \\
\text { promotion, } \\
\text { immunizations, } \\
\text { F.P., U-5 and } \\
\text { ante-natal clinics } \\
\text { Home delivery }\end{array}$ & $\begin{array}{l}\text { Treatment control } \\
\text { absentee tracing } \\
\text { Ulcer care } \\
\text { Education for disabled } \\
\text { Contact control }\end{array}$ & $\begin{array}{l}\text { Special follow-up } \\
\text { treatment control, } \\
\text { absentee tracing, } \\
\text { BCG, } \\
\text { Contact control }\end{array}$ & \\
\hline $\begin{array}{l}\text { General } \\
\text { population }\end{array}$ & $\begin{array}{l}\text { Promotion of } \\
\text { traditional midwives } \\
\text { Pregnancy register } \\
\text { Birth register } \\
\text { Health awareness } \\
\text { Promotion }\end{array}$ & $\begin{array}{l}\text { Leprosy awareness } \\
\text { Promotion } \\
\text { Treatment delivery } \\
\text { Contact register } \\
\text { Suspect register }\end{array}$ & $\begin{array}{l}\text { TB awareness } \\
\text { promotion } \\
\text { Treatment delivery } \\
\text { Contact register } \\
\text { Suspect register }\end{array}$ & $\begin{array}{l}\text { Village } \\
\text { Clinic/Worker }\end{array}$ \\
\hline
\end{tabular}

Figure 5. Mother and child health care, leprosy control and tuberculosis control integrated in a horizontal setting. LHA, Local Health Authority. (Loretti \& Carvalho 1986).

numbers affected decrease, but the cost of intervention at the intermediate and superior levels progressively increases.

Figure 4 is a development of Figure 2 showing the operational levels of the health services and the activities of primary, secondary and tertiary prevention which constitute a continuous flow, from the basic comprehensive services to the most specialized. At each point there is an outlet, which returns the patient/user to the general population. In the health structures column, the area of management and supervision normally entrusted to the local health authority (LHA) is shown as being from the district hospital downwards.

In Figure 5, the activities are listed and the target groups of the population linked directly to the operational structure. In this example, leprosy control is shown together with $\mathrm{MCH}$ and $\mathrm{TB}$ control, but the model could well be enlarged to include other PHC programmes. It is necessarily merely a summary, aiming to systematize levels of activity and distribution of tasks. Possible ways of integration will be suggested by reading transversely; practical details have to be added as local conditions dictate. The various activities have to be analysed in terms of the tasks and techniques involved, compared with the competences and resources available at each level and then planned according to local conditions of demography and morbidity. In addition, provision must be made 


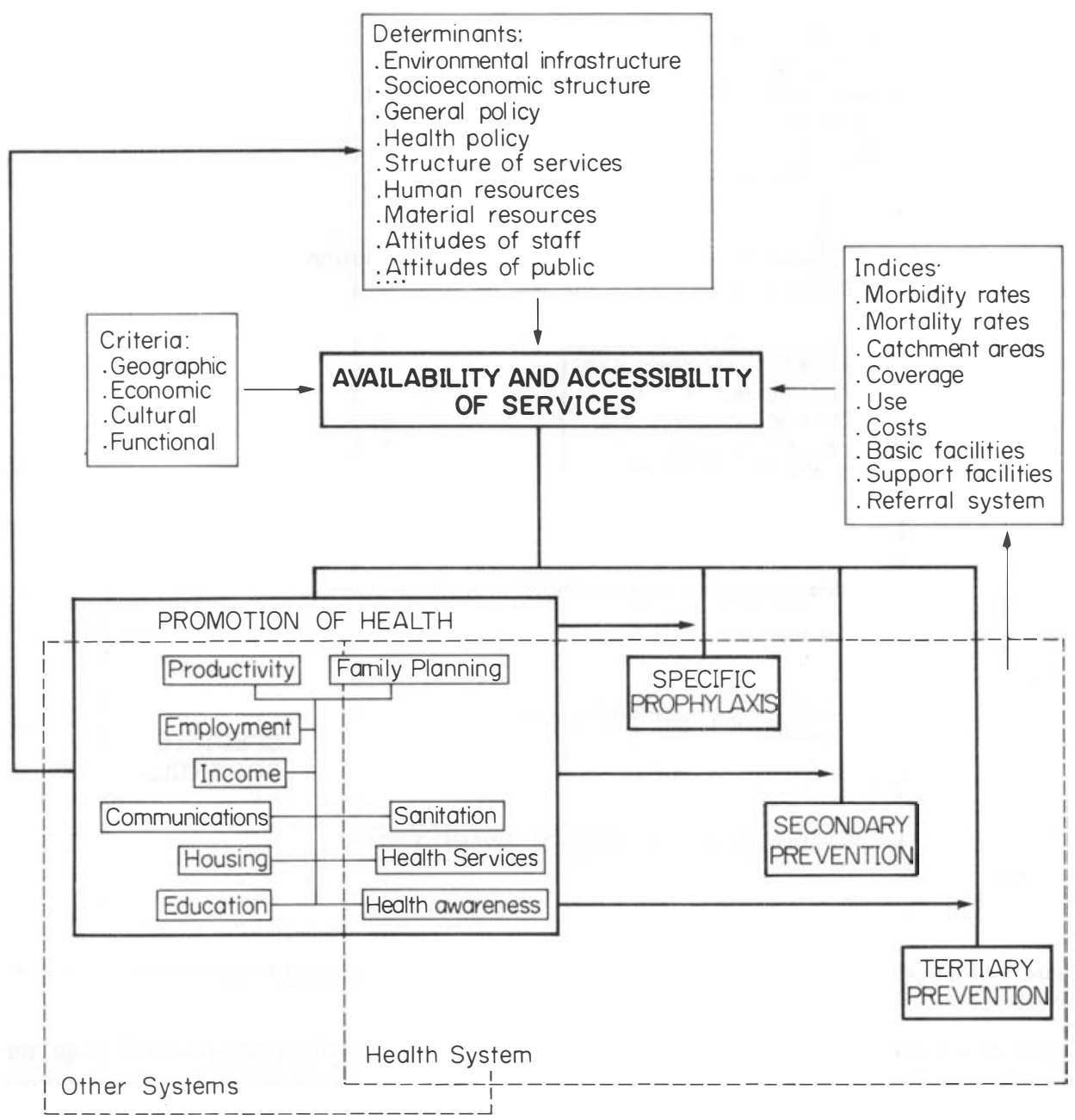

Figure 6. Availability and accessibility of services, promotion of health and prevention of disease (Loretti 1987).

for management and logistics, normally carried out at higher levels, and the integration of vertical programmes may well entail strengthening the administrative resources of the general health service.

\section{The activities analysis}

The second analysis concerns the extent to which leprosy control activities can be adapted to other objectives.

Figure 6 relates the promotion of health, prophylaxis, secondary and tertiary prevention, to the availability and accessibility of services, as conditioned by a number of determinants, defined by certain criteria and measured by several indices coming from data collected by the health system.

Figure 7 shows that promotion of health must take into account various socio-economic components, some of which are the responsibility of the health system: family planning, sanitation, 


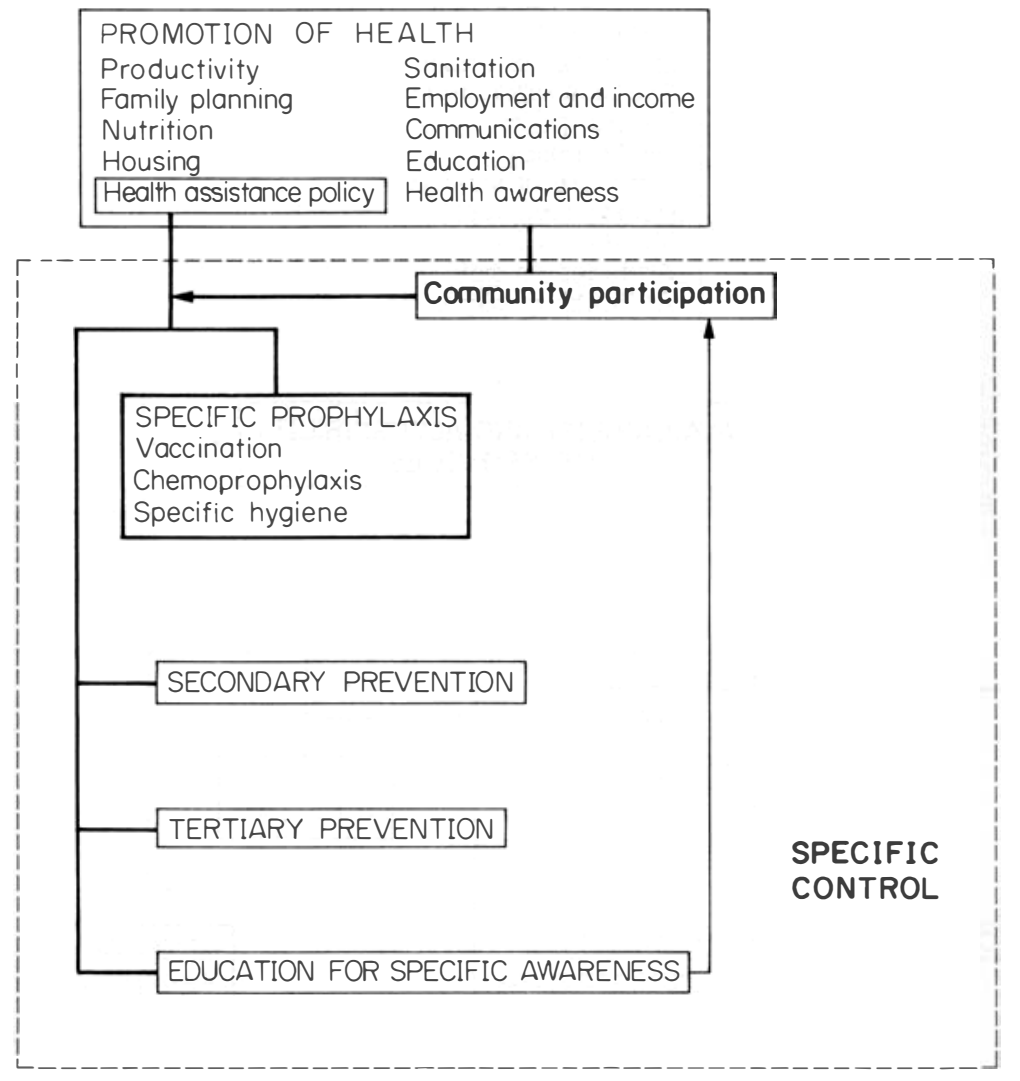

Figure 7. Promotion of health, prophylaxis, disease prevention, community participation and disease control (Loretti 1987).

health awareness and overall health policy. Health policy defines the specific control programme, but unless all the components of the promotion of health are being fulfilled, it will not enjoy full community participation, which in any case has to be fostered by education for public awareness to the problem.

Figure 8 shows that the health education of the population is essential for any programme and that it receives feedback from the outcome of the activities implemented. In leprosy control, reliance is still at present on secondary prevention, with two provisos: firstly, that tertiary preventionrehabilitation-contributes to health education by limiting disabilities; secondly, that specific prophylaxis, that is the reduction of specific risk in the community, is limited to the control of regularity of treatment and absentee tracing, which are both tasks of the basic worker and should be given due merit accordingly.

Figure 9 analyses secondary prevention by early detection and effective treatment in greater detail and systematizes their principal components. It makes it possible to identify items needing emphasis in some circumstances, e.g. the definition of the population being surveyed, the importance of an early diagnosis of complications, the role of a workable registration system, and the distribution of different therapeutic measures at various levels. For both early detection and effective treatment there are listed resources, criteria for quality control, basic requirements and a number of indices for the purpose of evaluation.

Figure 10 is a composite table showing how leprosy and other conditions can be considered together in an integrated approach. It includes: 


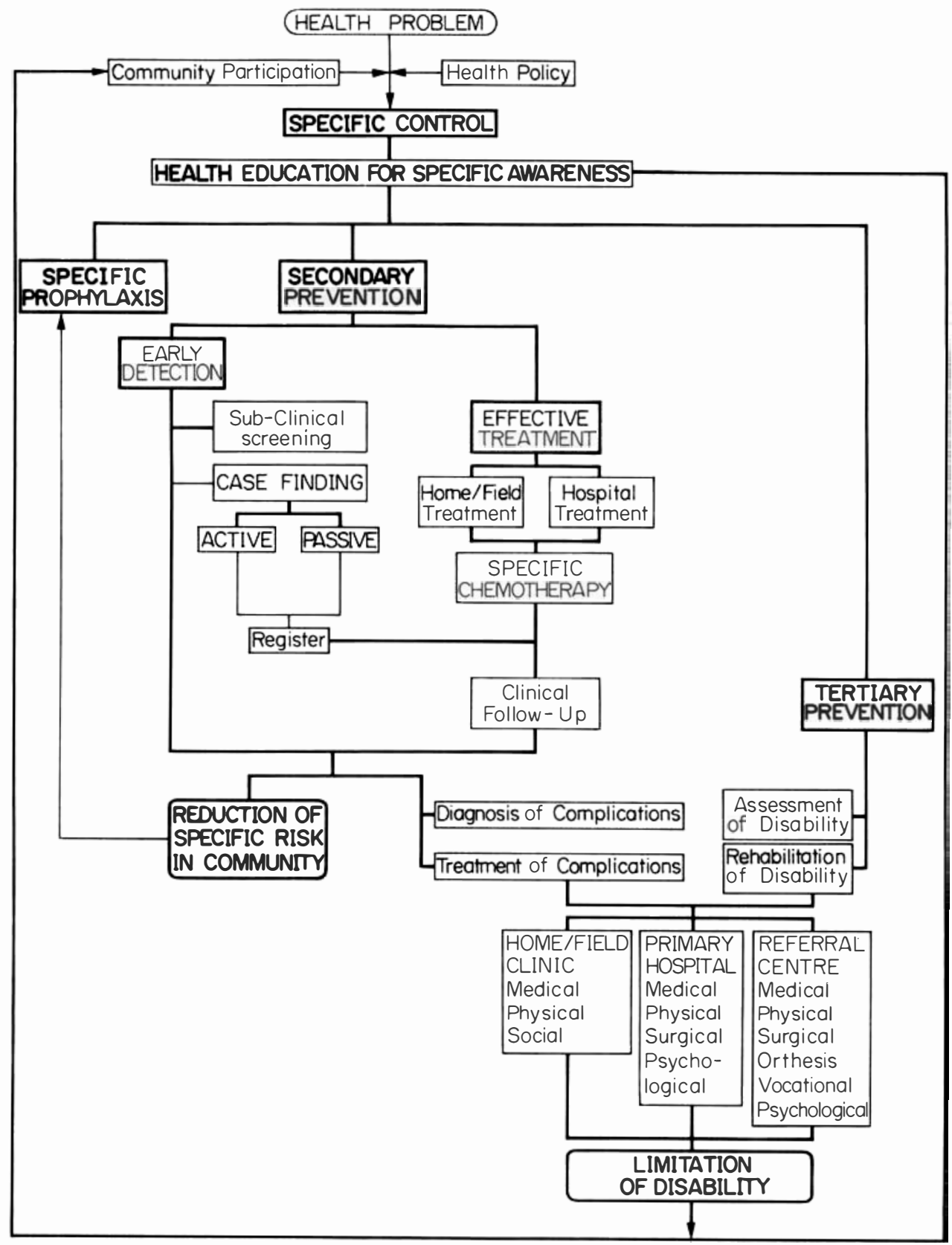

Figure 8. Model for control of infectious diseases based on secondary prevention. 


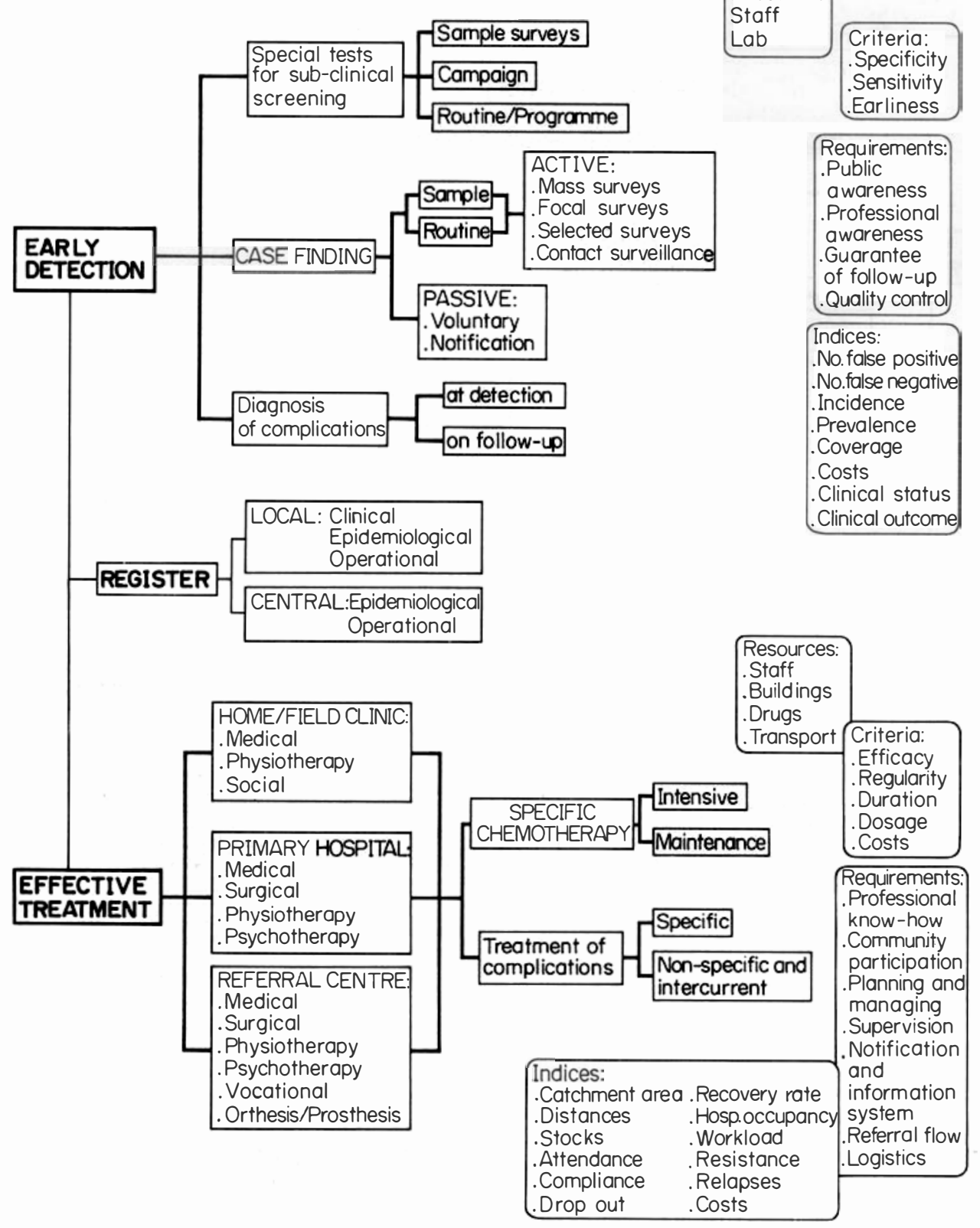

Figure 9. Secondary prevention: activities, resources, requirements, criteria and indices for evaluation. 


\begin{tabular}{|c|c|c|}
\hline ISSUE & MOST FEASIBLE INTEGRATION & RATIONALE \\
\hline $\begin{array}{l}\text { ACCESS TO SERVICES: } \\
\text { - effective coverage of population } \\
\text {. human and material resources } \\
\text { - technical know-how } \\
\text { - attitudes of staff } \\
\text { - attitudes of population }\end{array}$ & \begin{tabular}{|ll|}
\multicolumn{2}{c|}{ Leprosy and } \\
Tuberculosis & Mental disorders \\
Epilepsy & Sex.transm. dis's. \\
Asthma & Diabetes
\end{tabular} & $\begin{array}{l}\text { Same need for community involvement } \\
\text { Similar problems with patients' } \\
\text { attendance and compliance } \\
\text {. Same/similar social stigma } \\
\text { and demotivation of staff } \\
\text {. Same need for lengthy treatment } \\
\text { Same need for updating the curricula }\end{array}$ \\
\hline 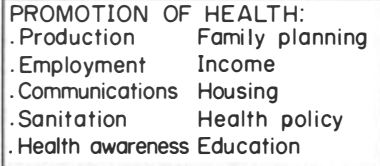 & $\begin{array}{l}\text { Leprosy and } \\
\text { all 'poverty diseases' }\end{array}$ & By historically evident relationship \\
\hline $\begin{array}{l}\text { SPECIFIC PROPHYLAXIS: } \\
\text { Specific vaccination }\end{array}$ & $\begin{array}{l}\text { Polio, pertussis, tuberculosis, } \\
\text { tetanus, diptheria, measles and } \\
\text { leprosy }\end{array}$ & $\begin{array}{l}\text { Same overall strategy } \\
\text { Same target group } \\
\text { Same logistic needs } \\
\text { Similar evaluation problems }\end{array}$ \\
\hline Immunological tests & $\begin{array}{c}\text { Leprosy and tuberculosis } \\
\text { AIDS } \\
\text { B-hepatitis }\end{array}$ & $\begin{array}{l}\text { Same strategic problems } \\
\text { Similar logistic problems } \\
\text { Similar interpretation problems }\end{array}$ \\
\hline $\begin{array}{l}\text { CASE FINDING: } \\
\text {.ACTIVE } \\
\text { Mass surveys } \\
\text { Focal surveys } \\
\text { Selected surveys } \\
\text { Contact surveillance }\end{array}$ & \begin{tabular}{|ll}
\multicolumn{2}{c}{ Leprosy and } \\
Tuberculosis & Nutritional \\
Epilepsy & disorders \\
Asthma & Mental diseases \\
Diabetes & Hypertension \\
& Parasitosis
\end{tabular} & $\begin{array}{l}\text { Use of multipurpose screenings } \\
\text { Use of basic level screening } \\
\text { subject to qualified confirmation } \\
\text { Same interest for community } \\
\text { involvement in the case } \\
\text { Same need for immediate family check }\end{array}$ \\
\hline \multirow{2}{*}{$\begin{array}{l}\text { PASSIVE } \\
\text { Regular clinic }\end{array}$} & \multirow[b]{2}{*}{ Leprosy and skin conditions } & Laboratory essential for Leprosy and TB \\
\hline & & Same clinical branch: diff. diagnosis \\
\hline $\begin{array}{l}\text { TREATMENT and FOLLOW-UP: } \\
\text {.HOME/FIELD CLINIC } \\
\text { by PH Workers with supervision }\end{array}$ & \begin{tabular}{|ll|}
\multicolumn{2}{|c|}{ Leprosy and } \\
Tuberculosis & Diarrhoeal diseases \\
Epilepsy & Hypertension \\
Asthma & Mental disorders \\
Diabetes & Nutritional \\
& disorders
\end{tabular} & $\begin{array}{l}\text { Administration of standard } \\
\text { treatment by primary level staff } \\
\text { Same need for compliance control } \\
\text { Same need for family participation } \\
\text { Same need for supervision of treatment } \\
\text { Same need for early diagnosis of } \\
\text { complications }\end{array}$ \\
\hline $\begin{array}{l}\text { HOSPITAL } \\
\text { in general hospital } \\
\text { or specialized referral centre }\end{array}$ & \begin{tabular}{|l|}
\multicolumn{2}{|c|}{ Leprosy and } \\
Skin conditions Trauma sequelae \\
Polio sequelae Trophic disorders \\
Neurological sequelae
\end{tabular} & $\begin{array}{l}\text { Need for long-term admission } \\
\text { Many common needs: physiotherapy, } \\
\text { surgery, orthesis, vocational therapy, } \\
\text { psychotherapy, social rehabilitation } \\
\text { health education }\end{array}$ \\
\hline $\begin{array}{l}\text { EDUCATION FOR HEALTH: } \\
\text {.TO GENERAL PUBLIC } \\
\text { prophylaxis, early signs; } \\
\text { treatment and cure } \\
\end{array}$ & 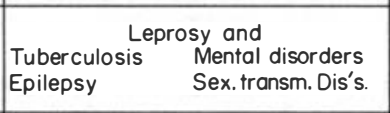 & $\begin{array}{l}\text { Similar social stigma against disease } \\
\text { Similar social stigma against patients } \\
\text { Similar need for community involvement } \\
\text { Same concern for early diagnosis }\end{array}$ \\
\hline $\begin{array}{l}\text { TO THE PATIENT } \\
\text { "regular treatment, self esteem, } \\
\text { complications" }\end{array}$ & \begin{tabular}{|l|} 
Lerosy and \\
Tuberculosis $\quad$ Polio sequelae \\
Trauma sequelae Neurological disorders
\end{tabular} & $\begin{array}{l}\text { Similar patterns of treatment } \\
\text { Similar risks of complication } \\
\text { Similar kind of self-care needed }\end{array}$ \\
\hline $\begin{array}{l}\text { INFORMATION SYSTEM: } \\
\text { EPIDEMIOLOGICAL DATA } \\
\text { Local and Central Register }\end{array}$ & \begin{tabular}{|l|}
\multicolumn{1}{c|}{ Leprosy and } \\
Tuberculosis, malnutrition, all other \\
diseases subject to surveillance
\end{tabular} & $\begin{array}{l}\text { Same interest in permanent monitoring } \\
\text { of Incidence and Prevalence }\end{array}$ \\
\hline $\begin{array}{l}\text { OPERATIONAL DATA } \\
\text { Activity register } \\
\text { (Treatment, Surveys, etc.) }\end{array}$ & $\begin{array}{l}\text { Leprosy control activities and } \\
\text { TB control, M C Health Care, EPI }\end{array}$ & $\begin{array}{l}\text { Same interest in permanent monitoring } \\
\text { of coverage, effectiveness, efficacy and } \\
\text { efficiency }\end{array}$ \\
\hline
\end{tabular}

Figure 10. Leprosy control: how specific items are suitable to cover other conditions (Loretti 1987).

global strategies, when common causes are recognized for otherwise dissimilar problems; practical activities, which are more efficient when directed to more than one goal; and methods, where conditions affecting patients and community in similar ways call for a similar approach and attitude.

As might be expected, conditions appearing most frequently in Figure 10 are other chronic infectious diseases, those carrying loss of self-esteem and those associated with social stigma. The association of leprosy with tuberculosis is already well accepted but what may be new is the idea that any activity relevant to leprosy control can be applied to facilitate access to health care for a number of conditions, and vice versa. 


\section{Conclusion}

Textbooks teach us that health is an integral entity and that there is no point in stating that 'disease $\mathrm{X}$ is like any other disease'- arising from the interaction of various biological, social and economic factors-if in practice we act as if only 'our' disease was real. Indeed, the average man recognizes this in his daily life, albeit unconsciously.

It is proper to give a problem, or even just one of its facets, priority when an effective remedy is available, but care has to be taken not to def eat objectives through the means. Vertical programmes are authoritarian in their definition and essence and have a negative impact upon health awareness, reducing patients to mass consumers of prepacked goods and worse, failing to meet all their felt needs. We all know the result: poor public participation in the programmes and poor patient compliance, both of which we try to improve by health education. Poor public participation contributes to demotivation and deterioration of standards and attitudes on the part of staff and this blatantly contradicts the message of our health education and counterbalances the advantage arising from concentration of effort. Accordingly, an integrated approach to our professional activities contributes more to the growth of awareness in the public than any specific health education programme.

Integration is feasible if supervision, which is a sine qua non, can be guaranteed. The current structure of health services in most leprosy endemic countries allows for a suitable distribution of specific activities at various operational levels, so that the features of leprosy control, from policy setting to the most basic tasks, can be exploited for other conditions.

All too often, there is a gap between the political statement of intent, e.g. 'Integration', and its practical implementation. To ensure the optimum utilization of human resources this gap has to be filled by a synthesis between policy and practice and for this, public health as a science, and systems analysis as a method, constitute the most effective tools.

\section{References}

1 Loretti A. 6 years of leprosy control in Cape Yerde. ILEP's XXXI Working Session, Yenezia, 1984.

2 Revankar CR. et al. Integration of leprosy into general hospital services in an Urban Area. Lepr Rev, 1982; 53: 297-305.

3 Nkinda SJ. Leprosy and primary health care: Tanzania. Lepr Rev, 1982; 53: 165-73.

${ }^{4}$ Saikawa K. The effect of rapid socioeconomic development on the frequency of leprosy in a population. Lepr Rev, 1981; 52: (Suppl 1), 167-75.

5 Shears P. Guidelines for tuberculosis control programmes in developing countries. Oxf am Practical Guide n. 4, 1985.

6 Hogerzeil LM, Kesava Reddy P. General education as the main approach to leprosy control. Dichpalli, India. Lepr Rev, 53: 195-9.

7 Buchmann H. Leprosy control services as an integral part of primary health care programs in developing countries. DAHW, 1978: The potential benefit of primary health care to leprosy control. Lepr Rev, 1982; 53: 211-20.

8 Ross WF. Leprosy and primary health care. Lepr Rev, 1982; 53: 201-4.

9 Leavell H, Gurney Clark E. Preventive medicine for the doctor in his community. McGraw-Hill, 1965.

\section{Further Reading}

Antia NH. Leprosy and primary health care: the Mandwa Project, India. Lepr Rev, 1982; 53: 205-9.

Bijleveld I. In reality: a medical anthropologist's reservations about the viability of leprosy control within P.H.C. Lepr Rev, 1982; 53: 181-92.: Kusta in North Sulawesti: fact and fiction. A study of social-cultural and medical service factors influencing leprosy control. NSL, 1982.

Loretti A. Leprosy Control: A conceptual model (1986) under publication: Programas de cuidados primarios e sistema de saude, 2nd National Conference, Ministerio da Saude, Trabalho e Assuntos Sociais de Cabo Verde, 1986: Salute: Infrastruttura e struttura, AIFO, 1987.

WHO: Primary health care, Alma-Ata 1970, Geneva 1970. 